\title{
PENGARUH PENGETAHUAN KEWIRAUSAHAAN DAN LINGKUNGAN KELUARGA TERHADAP MINAT BERWIRAUSAHA SISWA KELAS XI SMKN 1 DLANGGU KABUPATEN MOJOKERTO
}

\author{
Sundari, Muhammad Mujtaba Mitra Zuana \\ Institut Pesantren KH. Abdul Chalim Mojokerto \\ Email: Sundarifreste89@gmail.com; mujtaba.mitrazuana@ikhac.ac.id
}

\begin{abstract}
The interest of entrepreneurship is influenced by several factors such asentrepreneurial knowledge and family environment. The result of preliminary observation inSMKN 1 DlangguComal showed that the entrepreneurship interest of the eleventh graderstudents in the academic year of 2016/2017 was still considered poor. On the other hand, theirentrepreneurial knowledge was pretty high as well as their family environment which wasconsidered good. The objectives of this study were 1) to find out whether or not there is aninfluence of entrepreneurial knowledge on entrepreneurship interest of the eleventh graderstudents of SMKN 1 DlangguComal in the academic year of 2016/2017, 2) to find out theinfluence of family environment on entrepreneurship interest of the eleventh grader students ofSMKN 1 DlangguComal in the academic year of 2016/2017, 3) to find out the influence ofbothentrepreneurial knowledge and family environment on entrepreneurship interest of theeleventh grader students of SMKN 1 DlangguComal in the academic year of 2016/2017.The population of this study was the eleventh grader students of SMKN 1 DlangguComalin the academic year of 2016/2017 as many as 316 students. The number of sample was 76students decided by using Slovin calculation formula and chosen using proportional randomsampling technique. The methods of collecting the data were test, questionnaire, anddocumentation. While the methods of analyzing the data were using percentage descriptivetechnique and multiple linear regression analysis. The result of this study based on theregression analysis it was found that $Y=-6,787+0,493 X 1+0,170 X 2$. The result ofhypothesis testing in partial showed that the variable of entrepreneurial knowledge positivelyinfluenced the entrepreneurship interest by $32,60 \%$ and family environment positivelyinfluenced by $18,40 \%$. While simultaneously, the influence of entrepreneurial knowledge andfamily environment on entrepreneurship interest was $52,70 \%$ and the rest $47,30 \%$ wasexplained by other factors beyond the model of this study.
\end{abstract}

Keywords: Enterpreneurial Knowledge, Family Environment, Interest in Entrepreneurship

\section{ABSTRAK}

Minat kewirausahaan dipengaruhi oleh beberapa faktor seperti pengetahuan kewirausahaan dan lingkungan keluarga. Hasil pengamatan pendahuluan di SMKN 1 DlangguComal menunjukkan bahwa minat berwirausaha siswa kelas sebelas tahun ajaran 2016/2017 masih tergolong buruk. Di sisi lain, pengetahuan kewirausahaan mereka cukup tinggi serta lingkungan keluarga mereka yang dianggap baik. Tujuan penelitian ini adalah 1) untuk mengetahui ada atau tidaknya pengaruh pengetahuan kewirausahaan terhadap minat berwirausaha siswa kelas XI SMKN 1 Dlanggu Comal pada tahun akademik 2016/2017, 2) untuk mengetahui pengaruh lingkungan keluarga terhadap minat berwirausaha siswa kelas sebelas SMKN 1 Dlanggu Comal pada tahun akademik 2016/2017, 3) untuk mengetahui pengaruh pengetahuan kewirausahaan dan lingkungan keluarga terhadap minat berwirausaha siswa kelas sebelas SMKN 1 DlangguComal di tahun akademik 2016/2017. Populasi penelitian ini adalah siswa kelas XI SMKN 1 DlangguComal pada tahun akademik 2016/2017 sebanyak 316 siswa. Jumlah sampel 76 siswa yang ditentukan dengan menggunakan rumus perhitungan 
Slovin dan dipilih menggunakan teknik proporsional random sampling. Metode pengumpulan data adalah tes, kuesioner, dan dokumentasi. Sedangkan metode analisis data menggunakan teknik deskriptif persentase dan analisis regresi linier berganda. Hasil penelitian ini berdasarkan analisis regresi diketahui bahwa $Y=-6.787+0,493 X 1+0,170$ X2. Hasil pengujian hipotesis secara parsial menunjukkan bahwa variabel pengetahuan kewirausahaan berpengaruh positif terhadap minat berwirausaha sebesar 32,60\% dan lingkungan keluarga secara positif dipengaruhi oleh $18,40 \%$. Sementara secara simultan, pengaruh pengetahuan kewirausahaan dan lingkungan keluarga terhadap minat berwirausaha adalah 52,70\% dan sisanya 47,30\% dijelaskan oleh faktor-faktor lain di luar model penelitian ini.

Kata kunci: Pengetahuan Enterpreneurial, Lingkungan Keluarga, Minat Kewirausahaan

\section{PENDAHULUAN}

Berdasarkan peraturan Pemerintah Nomor 19 Tahun 2005 dan Peraturan Menteri PendidikanNasional Repulik Indonesia Nomor 23 Tahun 2006, standar kompetensi lulusan padaSMK yaitu menghasilkan lulusan yang siap menjadi tenaga kerja atau berwirausaha danmelanjutkan pendidikan yang lebih tinggi sesuai dengan kejuruannya. MenurutPeraturan Pemerintah No. 66 Tahun 2010, Sekolah Menengah Kejuruan (SMK)merupakan salah satu bentuk pendidikan formal kejuruan pada jenjang pendidikanmenengah. SMK merupakan pendidikan menengah kejuruan sebagai lanjutan dari SMP,MTs atau bentuk lain yang sederajat/diakui sama/setara SMP atau MTs. SMKmenghasilkan tenaga kerja tingkat menengah, sehingga siswa diharapkan siap kerja danmemiliki peluang besar untuk ikut dalam mengembangkan ekonomi melaluikewirausahaan. Siswa SMK setelah lulus akan mencari pekerjaan sesuai dengankeahlian yang dimiliki. Walaupun demikian tidak semua lulusan SMK mendapatkanpekerjaan, sehingga dapat menimbulkan pengangguran.Suwati (2008:4345) menyatakan bahwa setiap tahun jumlah lulusan sekolahsangatlah banyak. Semua lulusan lebih banyak mengarahkan langkahnya untuk mencaripekerjaan, bahkan untuk sekolah yang sebenarnya mengarahkan pembelajarannyamenuju jenjang pendidikan lebih tinggi, ternyata lulusannya ikut bersaing dalammencari pekerjaan. Jika kondisi saat ini terus berlanjut, maka pada saatnya nanti akanberjubel pengangguran terdidik, pengangguran intelektual. Hal ini belum termasuk paralulusan perguruan tinggi yang ternyata juga juga masih harus mencari pekerjaan.Sekolah kejuruan mempunyai peranan yang sangat penting di dalam upayamengarahkan anak didik sehingga mempunyai kesadaran bahwa berwirausahamerupakan alternatif terpenting 
menghadapi kehidupan yang semakin ketatpersaingannya. Hal ini mengandung pengertian bahwa sekolah hanyalah sebuah batuloncatan untuk menciptakan pekerjaan sesuai dengan bidang keahlian yang diikutinyadan bukan mengharapkan mendapatkan pekerjaan dengan mencari pekerjaan disekeliling kota.

Berkaitan dengan uraian di atas, maka sekolah kejuruan haruslah dapatmemberikan proses yang benar-benar efektif dalam bidang keterampilan kejuruannya.Proses ini diikiuti dengan penegasan kepada anak didik bahwa sebenarnya bersekolahitu bukan semata-mata untuk mempermudah mencari pekerjaan. Bersekolah di sekolahkejuruan merupakan pola pembelajaran yang lebih ditekankan untuk menciptakanorang-orang yang mampu bekerja, bukan yang mampu mencari pekerjaan. Implementasinya adalah dengan menciptakan lapangan pekerjaan yang berbasis pada bekal keterampilan yang didapatkannya dari proses pembelajaran.Untuk mengarahkan anak didik agar mempunyai pola pemikiran sebagaimana yang diinginkan, maka mindset anak harus ditekankan pada upaya usaha mandiri daripada mengharapkan pekerjaan dari orang lain. Sebaiknya menciptakan pekerjaan jauh lebih baik daripada mengharapkan pekerjaan dari orang lain. Untuk membentuk manusia yang berjiwawirausaha dan mampu melakukan wirausaha pada siswa SMK, maka yang harustertanam dahulu adalah minat untuk berwirausaha itu sendiri.

Menurut Slameto (2010:180) minat adalah suatu rasa lebih suka dan rasaketerikatan pada suatu hal atau aktivitas, tanpa ada yang menyuruh. Minat padadasarnya adalah penerimaan akan suatu hubungan antara diri sendiri dengan sesuatu diluar diri. Minat berwirausaha akan menjadikan seseorang lebih giat mencari danmemanfaatkan peluang usaha dengan mengoptimalkan potensi yang dimiliki. Minatberwirausaha merupakan keinginan, ketertarikan, serta kesediaan individu untuk bekerjakeras dalam memenuhi kebutuhan hidupnya tanpa takut dengan resiko yang akanterjadi.

Minat berwirausaha akan menjadikan seseorang lebih giat mencari danmemanfaatkan peluang usaha dengan mengoptimalkan potensi yang dimiliki. Minatberwirausaha merupakan keinginan, ketertarikan, serta kesediaan individu untuk bekerjakeras dalam memenuhi kebutuhan hidupnya tanpa takut dengan resiko yang akanterjadi. Minat berperan sangat penting dalam kehidupan peserta didik dan mempunyaidampak yang 
besar terhadap sikap dan perilaku. Siswa yang memiliki minat terhadapsesuatu cenderung mempunyai ketertarikan untuk mengetahui dan mempelajari hal-halyang berkaitan dengan minat tanpa adanya paksaan. Seseorang dikatakan memilikiminat berwirausaha yang tinggi dapat dilihat dari berbagai aspek kepribadian seperti watak, sikap dan perilaku seseorang.

Menurut Suryana (2013:22) ciri-ciri wirausaha memiliki enam komponen pentingyaitu percaya diri, berorientasi pada hasil, berani mengambil resiko, kepemimpinan,keorisinalitasan dan berorientasi pada masa depan. Menurut Slameto (1995) dalamKhairani (2013:145) bahwa minat sebagai salah satu aspek psikologis dipengaruhi olehbeberapa faktor, baik yang sifatnya dari dalam (internal) maupun dari luar (eksternal).Dilihat dari dalam diri siswa, minat dipengaruhi cita-cita, kepuasan, kebutuhan, bakat,dan pengetahuan. Sedangkan bila dilihat dari faktor luarnya minat sifatnya tidakmenetap melainkan dapat berubah sesuai dengan kondisi lingkungan. Faktor luartersebut dapat berupa kelengkapan sarana dan prasarana, pergaulan dengan orang tuadan persepsi masyarakat terhadap suatu objek serta latar belakang sosial budaya.Pembekalan pengetahuan kewirausahaan kepada siswa-siswa SMK sangat perludilakukan. Semakin tinggi pengetahuan kewirausahaan siswa SMK akan semakinterbuka wawasannya tentang kewirausahaan. Hasil penelitian terdahulu menyimpulkanbahwa pengetahuan kewirausahaan berpengaruh terhadap minat berwirausaha. Sekolahidealnya dapat membantu pembentukan minat siswa berwirausaha. Namun, masihbanyak SMK hanya menitikberatkan pembelajaran pada aspek pengetahuan saja danbelum mampu mengkondisikan lingkungan sekolah yang dapat menumbuhkan minat

siswa berwirausaha. Pengetahuan kewirausahaan merupakan salah satu faktor pemicuminat berwirausaha. Seseorang yang telah memeroleh pelatihan, seminar, kursuskewirausahaan akan tertarik untuk berwirausaha.

Mata pelajaran kewirausahaan merupakan salah satu pelajaran yang diajarkanpada kurikulum SMK. Pelajaran ini mencakup teori dan praktik kewirausahaan. Matapelajaran kewirausahaan SMK merupakan salah satu bentuk pemberian pengetahuankewirausahaan kepada siswa agar siswa berminat untuk menekuni bidangkewirausahaan. Materi pembelajaran kewirausahaan yang di 
dalamnya berisi tentanghal-hal yang berkaitan dengan kewirausahaan, yaitu langkahlangkah berwirausaha,bagaimana seseorang melakukan usaha ekonomi, dan sebagainya.Dengan adanyapengetahuan memungkinkan manusia mengembangkan ketrampilan yang berguna bagikehidupannya. Demikian halnya dengan pengetahuan kewirausahaan juga memilikiperan yang sangat penting dalam kegiatan kewirausahaan, karena pengatahuankewirausahaan adalah dasar dari sumber daya kewirausahaan yang terdapat dalam diriindividu. Tinggi rendahnya tingkat pengetahuan seseorang menurut Notoadmodjo(2003) dalam Wawan dan Dewi (2010:12-14) dipengaruhi oleh mengatahui, memahami,aplikasi, analisis, sintesis dan evaluasi.SMKN 1 DlangguComal memiliki program keahlian Akuntansi, TeknikKomputer dan Jaringan, dan Perbankan Syariah. Masing-masing program keahliantersebut memiliki tujuan yang berbeda satu dengan yang lainnya. Walaupun demikian,masing-masing program keahlian tersebut mendapat pembelajaran mengenaikewirausahaan sehingga mendidik siswa untuk minat berwirausaha.Hasil observasi awal di SMKN 1 DlangguComal pada saat ini menggunakanKurikulum Tingkat Satuan Pendidikan (KTSP) 2006.

Menurut guru mata pelajarankewirausahaan, selama proses pembelajaran kewirausahaan siswa aktif bertanya denganpertanyaan yang beragam. Ketika guru mengadakan kuis, siswa dapat menjawab setiappertanyaan dari guru. Dengan bekal informasi kewirausahaan yang telah siswa perolehmaka dapat menjawab pertanyaan dari guru. Hal tersebut menunjukkan bahwapengetahuan siswa sudah tinggi.Disamping bekal pengetahuan kewirausahaan, factorlain yang mempengaruhi minat berwirausaha adalah lingkungan keluarga. Lingkungankeluarga merupakan lingkungan pendidikan utama yang pertama kali diterima olehseorang anak, karena dalam keluarga inilah anak pertama kali mendapatkan pendidikandan bimbingan setelah dilahirkan. Dikatakan lingkungan utama, karena sebagiankehidupan anak berada di dalam keluarga, sehingga pendidikan yang paling banyakditerima oleh anak adalah di dalam keluarga. Di lingkungan keluarga tersebutperkembangan anak dan tingkah laku anak akan berpengaruh (Khairani, 2013:194).Pada observasi awal di SMKN 1 DlangguComal sebagian besar orang tuasiswa kelas XI rata-rata bermata pencaharian wirausaha, petani dan buruh. 
Beradsartan data pekerjaan orang tua siswa adalah wirausaha, sehingga di harapkan anaknya bisa melanjutkan usaha orang tua atau ikut menciptakan lapangan pekerjaan sendiri. Tetapi pada kenyataannya siswa lulusan SMK lebih memilih untuk mencari pekerjaan daripada menciptakan pekerjaan sendiri. Data siswa SMKN 1 DlangguComal tahun 2016/2017 menunjukan bahwasebagian besar siswa masih sedikit yang berwirausaha seperti terlihat pada tabel 2.Berdasarkan data siswa SMKN 1 DlangguComal tahun 2016/2017 total siswa yangberwirausaha adalah 26 siswa $(8,23)$. Bentuk usaha yang dijalankan oleh siswa kelas XISMKN 1 DlangguComal berupa menjual pulsa, makanan ringan, online shop, danlainlain. Hal ini menunjukan bahwa minat siswa untuk berwirausaha masihrendah.Berdasarkan masalah di atas, penting untuk dilakukan penelitian dengan judul'Pengaruh Pengetahuan Kewirausahaan dan Lingkungan Keluarga Terhadap MinatBerwirausaha Siswa Kelas XI SMKN 1 DlangguKabupaten Mojokerto”.

\section{MINAT BERWIRAUSAHA}

Menurut Slameto (2010:180) minat adalah suatu rasa lebih suka dan rasaketerikatan pada suatu hal atau aktivitas, tanpa ada yang menyuruh. Minat berwirausahamerupakan keinginan, ketertarikan, serta kesediaan individu untuk bekerja keras dalammemenuhi kebutuhan hidupnya tanpa takut dengan resiko yang akan terjadi. Menurut(Suryana, 2013:22), indikator dari minat berwirausaha meliputi (1) Percaya diri, (2)Berorientasi tugas dan hasil, (3) Pengambilan resiko, (4) Kepemimpinan, (5)Keorisinilan, (6) Berorientasi ke masa depan.

\section{PENGETAHUN KEWIRAUSAHAAN}

Menurut Notoatmodjo (2003) dalam Wawan dan Dewi (2010:11) pengetahuanadalah hasil "tahu" dan ini terjadi setelah orang mengadakan penginderaan terhadapsuatu objek tertentu. Suryana (2013:2) menjelaskan kewirausahaan adalah suatu disiplinilmu yang mempelajari tentang nilai, kemampuan, dan perilaku seseorang dalammenghadapi tantangan hidup dan cara memperoleh peluang dengan berbagai risiko yangmungkin dihadapinya. Pengetahuan kewirausahaan adalah keseluruhan yang diketahuitentang segala bentuk informasi berupa ingatan dan pemahaman tentang cara 
berusahasehingga menimbulkan keberanian mengambil risiko dalam merintis, menjalankan, danmengembangkan usaha. Pengetahuan kewirausahaan merupakan salah satu factorpemicu minat berwirausaha. Seseorang yang telah memeroleh pelatihan, seminar,kursus kewirausahaan akan tertarik untuk berwirausaha. Indikator pengetahuankewirausahaan yang dilihat dari silabus SMK mata pelajaran kewirausahaan kurikulumKTSP 2006 semester ganjil dan genap, meliputi (1) Menganalisis peluang usaha, (2)Menganalisis aspek-aspek perencanaan usaha, (3) Menyususun proposal usaha.

\section{LINGKUNGAN KELUARGA}

Khairani (2013:194) menjelaskan lingkungan keluarga merupakan pendidikan utama yang pertama kali diterima oleh seorang anak, karena dalam keluarga inilah anak pertama kali mendapatkan pendidikan dan bimbingan setelah mereka dilahirkan. Dikatakan lingkungan utama, karena sebagian kehidupan anak berada di dalamkeluarga, sehingga pendidikan yang paling banyak diterima oleh anak adalah di dalamkeluarga. Menerut Slameto (2010:60-64), indikator lingkungan keluarga sebagai berikut(1) Cara orang tua mendidik, (2) Relasi antar anggota keluarga, (3) Suasana rumah, (4)Keadaan ekonomi keluarga, (5) Pengertian orang tua, (6) Latar belakang kebudayaan.

\section{METODE PENELITIAN}

Populasi yang digunakan dalam penelitian ini adalah seluruh siswa kelas XI tahunajaran 2015di SMKN 1 DlangguComal sejumlah 316 siswa. Dalam penelitian inipengambilan sampel dengan menggunakan rumus Slovin diperoleh 76 siswa.Teknikpengambilan sampel menggunakan teknik proportional random sampling dengan caraundian. Metode pengumpulan data menggunakan metode tes, angket, dan dokumentasi.Sedangkan metode analisis data menggunakan teknik deskriptif presentase dan analisisregresi linear berganda.

\section{HASIL PENELITIAN DAN PEMBAHASAN}


Jumlah sampel dalam penelitian ini sebanyak 76 siswa dari total populasi 316siswa. Berdasarkan analisis deskriptif presentase diperoleh rata-rata minat berwirausahasiswa sebesar 51,22\% termasuk dalam kategori kurang tinggi. Rata-rata pengetahuankewirausahaan siswa yaitu 78 termasuk dalam kategori baik. Sedangkan rata-ratalingkungan keluarga siswa sebesar 73,04\% termasuk dalam kategori baik.Pengujian hipotesis penelitian ini menggunakan analisis regresi linear bergandadengan dua variabel bebas yaitu pengetahuan kewirausahaan (X1) dan lingkungankeluarga (X2). Variabel terikatnya adalah minat berwirausaha (Y) sebagai berikut:

Berdasarkan hasil uji regresi berganda diatas, maka diperoleh persamaan regresi sebagai berikut :

$\mathrm{Y}=-6,787+0,439 \mathrm{X} 1+0,170 \mathrm{X} 2$

a. Konstanta $=-6,78$

Konstanta yang negatif tidak menjadi masalah, sepanjang X1 dan X2 tidakmungkin sama dengan nol, dan tidak mendekati -1 .

b. Koefisien $\mathrm{X} 1=0,43$

Nilai koefisien regresi variabel pengetahuan kewirausahaan adalah sebesar 0,439.Artinya jika terjadi suatu peningkatan dan penurunan nilai variabel sebesar 1,maka nilai variabel minat berwirausaha akan meningkat atau menurun sebesar0,439 dengan asumsi variabel lainnya tetap.

c. Koefisien $\mathrm{X} 2=0,170$

Nilai koefisien regresi variabel lingkungan keluarga adalah sebesar 0,170. Artinyajika terjadi suatu peningkatan dan penurunan nilai variabel sebesar 1, maka nilaivariabel minat berwirausaha akan meningkat atau menurun sebesar 0,170 denganasumsi variabel lainnya tetap.Uji statistik $F$ pada dasarnya menunjukan semua variabel independen atau bebasyang dimasukan dalam model regresi mempunyai pengaruh secara bersama-samaterhadap variabel dependen/terikat.

Pada uji regresi linear berganda menunjukkan bahwa nilai dari $\mathrm{F}$ hitung lebih besar dari pada 2 yaitu sebesar 40,600 dengan signifikansi $0,00 \overline{0} \quad 0,05$ maka Ho ditolak dan Ha3 diterima, yang berarti bahwa pengetahuan kewirausahaan dan lingkungan 
keluarga secara bersama-sama berpengaruh terhadap minat berwirausaha. Uji statistik t digunakan untuk menunjukan seberapa jauh pengaruh satu variablepenjelas/independen secara individual dalam menerangkan variansi variabel dependen.

Uji koefisien determinasi simultan (R2) digunakan untuk mengetahui seberapa besar pengaruh variabel pengetahuan kewirausahaan dan lingkungan keluarga terhadap minat berwirausaha dapat dilihat sebagai berikut :

Besarnya kontribusi pengetahuan kewirausahaan dan lingkungan keluarga terhadap minat berwirausaha diketahui dari nilai koefisien determinasi Adjusted R2 yaitu sebesar 0,527 atau $52,70 \%$ sehingga dapat diartikan bahwa 52,70\% variabel minat berwirausaha dijelaskan oleh variabel pengetahuan kewirausahaan dan lingkungan keluarga. Sedangkan sisanya 0,473 (1-0,527) atau 47,30\% dijelaskan oleh faktor-faktoryang lain diluar model.Uji koefisien determinasi parsial (r2) digunakan untuk mengetahui seberapa besarpresentase pengaruh variabel $\mathrm{X}$ (pengetahuan kewirausahaan dan lingkungan keluarga)terhadap Y (minat berwirausaha). Untuk mengetahui koefisien determinasi parsialdibutuhkan bantuan dengan menggunakan program SPSS pada uji parsial, yaitu tablecoefficients. Caranya adalah dengan menguadratkan nilai correlations partial dalamtabel, kemudian diubah ke dalam bentuk presentase.

Berikut adalah hasil koefisien determinasi model regresi berganda :

Berdasarkan uji koefisien determinasi parsial menunjukkan besarnya kontribusivariabel pengetahuan kewirausahaan terhadap minat berwirausaha secara parsial yaitu $(0,571) 2 \times 100 \%=32,60 \%$. Besarnya lingkungan keluarga terhadap minat berwirausahasecara parsial sebesar $(0,429) 2 \times 100 \%=18,40 \%$. Dengan demikian variablepengetahuan kewirausahaan memberikan pengaruh yang lebih besar terhadap minatberwirausaha dibandingkan dengan variabel lingkungan keluarga.

\section{PENGARUH PENGETAHUAN KEWIRAUSAHAAN TERHADAP MINAT BERWIRAUSAHA}

Hipotesis pertama Hal penelitian ini adalah ada pengaruh positif antarapengetahuan kewirausahaan terhadap minat berwirausaha siswa kelas XI SMKN 1 DlangguComal kabupaten Mojokerto tahun ajaran 2016/2017. Hasil 
analisismenunjukkan ada pengaruh pengetahuan kewirausahaan terhadap minat berwirausaha,yang artinya Hal diterima. Maka hipotesis yang berbunyi ada pengaruh positif antarapengetahuan kewirausahaan terhadap minat berwirausaha siswa kelas XI SMKN 1 DlangguComal tahun ajaran 2016/2017, diterima. Pengetahuan kewirausahaandiperoleh dari pembelajaran kewirausahaan. Pembelajaran kewirausahaan bertujuanuntuk membentuk peserta didik memiliki kemampuan berwirausaha. Hal ini sejalanadanya pengaruh yang kuat dengan pengetahuan kewirausahaan yang diperoleh daripembelajaran kewirausahaan dapat berupa pemahaman materi terhadap minatberwirausaha siswa. Siswa akan mempunyai minat berwirausaha apabila siswa tahusecara benar tentang seluruh karakteristik dalam dunia usaha. Pemahaman siswa tidakhanya bersifat parsial atau siswa hanya memahami hanya sebagian dari berwirausaha,akan tetapi siswa harus memahami secara keseluruhan seluk beluk wirausaha. Apabilasiswa hanya memahami hanya sebagian dari ciri-ciri berwirausaha, maka akancenderung menemui kegagalan karena siswa tidak mampu menganalisis secarakomprehensif tentang faktor internal dan faktor ekternal yang mampu mendukungkeberhasilan usaha yang dijalankan.

\section{PENGARUH LINGKUNGAN KELUARGA TERHADAP $\quad$ MINAT BERWIRAUSAHA}

Hipotesis kedua Ha2 dalam penelitian ini adalah ada pengaruh positif antaralingkungan keluarga terhadap minat berwirausaha siswa kelas XI SMKN 1 DlangguComal kabupaten Mojokerto tahun ajaran 2016/2017. Hasil analisis data dalampenelitian menunjukkan bahwa terdapat pengaruh lingkungan keluarga terhadap minatberwirausaha, yang artinya $\mathrm{Ha} 2$ diterima. Maka hipotesis yang berbunyi ada pengaruhpositif antara lingkungan keluarga terhadap minat berwirausaha siswa kelas XI SMKN 1 DlangguComal tahun ajaran 2016/2017, diterima. Terhadap pekerjaan orangtua, seringkali terlihat bahwa ada pengaruh dari orang tua yang bekerja sendiri, danmemiliki usaha sendiri cenderung anaknya jadi pengusaha pula. Keadaan ini seringkalimemberikan inspirasi pada anak sejak kecil. Situasi seperti ini akan lebih diperkuat lagioleh ibu yang juga ikut berusaha. Oran tua ini cenderung menyemangati 
AL-'ADALAH: Jurnal Syariah dan Hukum Islam

e-ISSN: 2503-1473

Hal. 107-119

Vol. 3, No. 2, Juli 2018

sertamendorong keberanian anaknya untuk berdiri sendiri. Suasana dorongan ini sangatpenting artinya bagi calon pengusaha. 


\section{KESIMPULAN DAN SARAN}

Ada pengaruh positif pengetahuan kewirausahaan terhadap minat berwirausahasiswa kelas XI SMKN 1 DlangguComal Kabupaten Mojokerto tahun ajaran2016/2017. Berdasarkan hasil analisis deskriptif presentase pada variablepengetahuan kewirausahaan diperoleh nilai rata-rata 78 dalam kategori baik. Berdasarkan hasil uji statistik pada variabel pengetahuan kewirausahaan diperoleh nilai t hitung sebesar 5,948 dengan signifikansi $0,000^{-} 0,05$ dan kontribusi variabel pengetahuan kewirausahaan terhadap minat berwirausaha secara parsial sebesar $32,60 \%$. Artinya semakin tinggi minat berwirausaha yang dimiliki siswa semakin tinggi pula pengetahuan kewirausahaan siswa.

Ada pengaruh positif lingkungan keluarga terhadap minat berwirausaha siswa kelas XI SMKN 1 DlangguComal tahun ajaran 2016/2017. Berdasarkan hasilanalisis deskriptif presentase pada variabel lingkungan keluarga dengan rata-rataklasikal $73,04 \%$ dalam kategori baik. Berdasarkan hasil uji statistik pada variablelingkungan keluarga diperoleh nilai $\mathrm{t}$ hitung sebesar 4,056 dengan signifikansi0,000- 0,05 dan kontribusi variabel lingkungan keluarga terhadap minatberwirausaha secara parsial sebesar 18,40\%. Hal ini berarti semakin baiklingkungan keluarga akan berpengaruh pada semakin tingginya minatberwirausaha siswa.

Ada pengaruh positif pengetahuan kewirausahaan dan lingkungan keluargaterhadap minat berwirausaha siswa kelas XI SMKN 1 DlangguComal tahunajaran 2016/2017. Uji statistik F menunjukan bahwa nilai dari F hitung lebih besardari pada 2 yaitu sebesar 40,600 dengan $0,000^{-} 0,05$ yang berarti pengetahuankewirausahaan dan lingkungan keluarga secara bersama-sama berpengaruhterhadap minat berwirausaha. Besarnya pengaruh kedua variabel tersebut terhadapminat berwirausaha adalah $52,70 \%$ sehingga dapat diartikan bahwa $52,70 \%$ variabel minat berwirausaha dijelaskan oleh variabel pengetahuan kewirausahaandan lingkungan keluarga, sedangkan sisanya 47,30\% dijelaskan oleh faktor-faktoryang lain diluar model.

Bagi siswa untuk lebih meningkatkan minat berwirausaha maka mind set anak harus ditekankan pada upaya usaha mandiri daripada mengharapkan pekerjaan dari 
orang lain. Dengan bekal mengikuti pelatihan, seminar, kursus kewirausahaan akan tertarik untuk berwirausaha.

Bagi pihak sekolah untuk lebih membekali pengetahuan kewirausahaan siswa baik melalui praktik maupun teori melalui proses pembelajaran di kelas. Semakin tinggi pengetahuan kewirausahaan siswa maka semakin terbuka wawasannya tentang kewirausahaan dan akan meningkatkan minat berwirausaha.

Bagi peneliti selanjutnya lebih baik menambahkan variabel lain karena berdasarkan penelitian ini variabel yang digunakan untuk mengukur pengaruh minat berwirausaha hanya sebatas pengaruh pengetahuan kewirausahaan dan lingkungan keluarga dan terdapat faktor lain yang mempengaruhi minat berwirausaha.

\section{DAFTAR PUSTAKA}

Khairani, Makmun. 2013. Psikologi Belajar. Yogyakarta: Aswaja Pressindo.

Peraturan Pemerintah Nomor 19 tahun 2005 Tentang Standar Kompetensi Lulusan padaSekolah Menegah Kejuruan.

Peraturan Pemerintah Nomor 66 Tahun 2010 Tentang Sekolah Menengah Kejuruan

Peraturan Menteri Pendidikan Nasional Republik Indonesia Nomor 23 tahun 2006

Tentang Standar Kompetensi Lulusan pada Sekolah Menegah Kejuruan.

Slameto. 2010. Belajar \& Faktor-faktor yang Mempengaruhi. Jakarta: Rineka Cipta.

Suharsimi, Arikunto. 2010. Prosedur Penelitian Suatu Pendekatan Praktik. Jakarta:Rineka Cipta.

Suharsimi, Arikunto. 2009. Dasar-Dasar Evaluasi Pendidikan Edisi Revisi. Jakarta:Bumi Aksara.

Suryana. 2013. Kewirausahaan Kiat dan Proses Menuju Sukses Edisi Empat. Jakarta:Salemba Empat.

Suwati. 2008. Sekolah Bukan Untuk Mencari Pekerjaan. Bandung: PT karya Kita.

Wawan, A, dan Dewi M. 2011. Teori \& Pengukuran Pengetahuan Sikap dan PerilakuManusia. Yogyakarta: Nuha Medika. 